\title{
Stemming the sportswear counterfeit tide: Emerging market evidence of rational and normative drivers
}

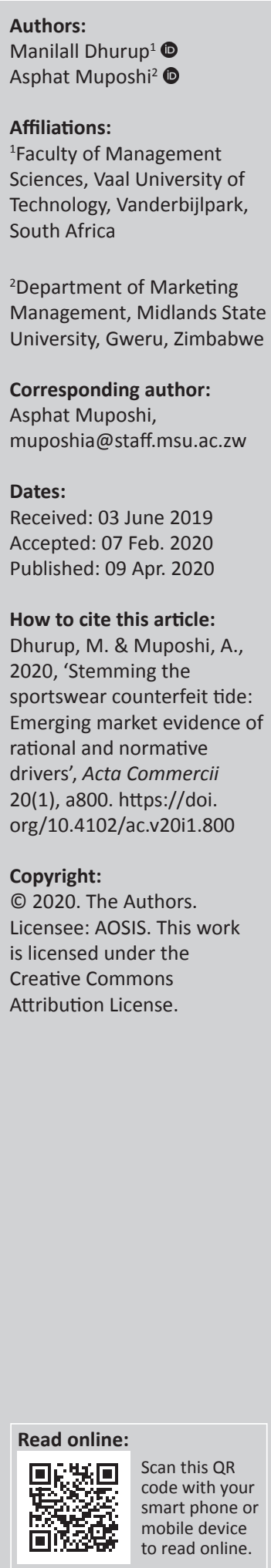

Orientation: Increasingly, there is an urgent need to curb the scourge of counterfeiting, which is fast becoming a global economic threat with severe implications on employment creation and societal well-being.

Research purpose: The aim of this study was to examine the effect of rational and normative factors on consumers' willingness to buy counterfeit sportswear in South Africa.

Motivation for the study: This study contributes input to the development of long-term strategies of curbing the escalating scourge of counterfeiting in the sportswear sector.

Research design, approach and method: The study was conducted in South Africa's southern Gauteng region and Johannesburg central business district, which are considered to be amongst the major counterfeit sportswear promoting segments in South Africa. Cross-sectional data were collected from a convenient sample of 390 respondents. Study hypotheses were tested using standard multiple regression analysis.

Main findings: Perceived financial control and subjective norm emerged as the main factors that engender favourable attitudes towards counterfeit products. Furthermore, attitude towards counterfeits had a strong positive effect on consumers' willingness to purchase counterfeit sportswear.

Practical/managerial implications: The findings of this study suggest that a combination of normative and rational strategies have the potential to change consumers' attitudes and willingness to purchase counterfeit sportswear.

Contribution/value-added: The study findings highlight the importance of attempting to address the problem of counterfeiting not only from a regulatory perspective but also from a rational and normative perspective.

Keywords: counterfeit; theory of planned behaviour; sportswear; South Africa; unethical consumerism.

\section{Introduction and background}

Because of the pervading force of globalisation, technological advancements and the relaxation of international trade barriers, consumers are increasingly being exposed to counterfeit products, wittingly or unwittingly (Meraviglia 2018; Perumal \& Sapihan 2017). Counterfeiting has now become a global scourge, fast growing in developed and emerging markets alike (Cheng, Fu \& Tu 2011). Counterfeiting (in South Africa, colloquially referred to as 'Fong Kong', and knock-offs, forging, brand piracy or replicas in other countries) is a practice whereby companies or individuals produce unauthorised goods whose features are designed to resemble those of intellectually protected or patented products (Perumal \& Sapihan 2017).

Conceptually, a counterfeit is described as an unauthorised product whose production, distribution and consumption violate intellectual property rights of an established brand (Swami, Chamorro-Premuzie \& Furnham 2009). It is also referred to as the unlawful copying and production of a patented product (Darmayanti \& Boediono 2012). Counterfeiting behaviour takes the form of either deceptive counterfeiting or non-deceptive counterfeiting. Deceptive counterfeiting is evident when consumers buy and consume a fake product unknowingly (Swami et al. 2009). Conversely, non-deceptive counterfeiting occurs when consumers knowingly purchase and consume counterfeit products (Chiu \& Leng 2016). This study focuses on nondeceptive counterfeiting, a form of unethical consumerism (Abraham, Takwin \& Suleeman 2018). 
Although accurate statistics of the actual value of the counterfeit industry are not readily available because of its unlawful nature, indicators point to its enormity. In 2015, it was estimated that counterfeit trade accounted for almost $2 \%$ of the total world trade, jeopardising almost 2.5 million formal job opportunities per annum (Ting, Goh \& Isa 2016). Moreover, counterfeits pose financial loss and dilution of brand reputation and brand equity to manufacturers of original sportswear (Perumal \& Sapihan 2017). At macroeconomic level, counterfeits result in loss in tax revenues, unemployment, slowing down of innovation and constrained economic growth (Ting et al. 2016).

Although counterfeiting affects several brands and product categories (Bian \& Moutinho 2011), it is perceived to be more rampant in the sportswear industry (OECD 2009; Transcrime 2010). For example, from 2012 to 2015, the National Football League reported that an estimated USD40 million (m) worth of counterfeit sporting goods were recovered in the United States (Umar 2015). In the sportswear sector, counterfeits are spurred by growth in the sports economy and relatively less technical knowhow required in production (Chiu \& Leng 2016). According to Formosa (2011), sportswear is a commonly imitated product in the sports industry as it is often associated with mega sporting tournaments such as the Soccer World Cup and Olympics, which entice counterfeit manufacturers to engage in mass production of fake sportswear.

\section{Contextual setting of the study}

As one of the biggest economies in Africa, South Africa is a prime target of counterfeit products (Cant, Wiid \& Manley 2014). The counterfeit industry is a thriving market in South Africa and is estimated to be worth approximately R362 billion (bn) (Montandon 2015; South African Revenue Service 2018). Counterfeit products find their way to South Africa aided by security lapses at ports of entry and porous border posts (Meissner 2010). In addition, South Africa has strong trade relations with China, which is regarded as the major producer of counterfeit products (Haman 2010). Furthermore, South Africa has several sea ports, which facilitate trade between countries (Shunmugam 2015) and such ports, unfortunately, are used to ship in counterfeit products. For example, a few weeks before the 2011 Rugby World Cup, the South African Revenue Services (SARS) seized a total of 66000 replica rugby jerseys, with an estimated value of R43 million (News24 2011). Also, during the period 01 April to 31 March 2018, counterfeit products with an estimated value of R2.3 billion were seized by the SARS with sportswear (footwear and apparel) amounting to over R500 m, which shows the magnitude of counterfeiting.

The demand of counterfeit sportswear products in South Africa is encouraged by growth in sporting culture and healthy living lifestyle, which place exercise behaviour at the fore (Shunmugam 2015).

Moreover, the lack of market appeal of local sportswear brands such as Flya and Panda promotes the uptake of counterfeits of popular global brands such as Nike, Adidas and Puma (News24 2011). In an attempt to curb the scourge of counterfeit, the South African government has mainly used coercive measures such as seizures and legislation in the form of the Counterfeit Goods Act 37 of 1997 (Shunmugam 2015).

Notwithstanding the implementation of these measures, counterfeit products continue to flood the markets (Montandon 2015).

\section{Aims and objectives}

Despite the prevalence of counterfeit products in the sportswear sector, research interest has been low. The majority of past studies predominately focused on counterfeits of luxury brands (Cant et al. 2014; Heike 2010; Kim \& Karpova 2010; Phau \& Teah 2009) and piracy (Liao, Lin \& Liu 2010). Notable studies on counterfeit sportswear include that of $\mathrm{Xi}_{\mathrm{i}}$ and Cheng (2017) in Malaysia, Dai and Chen (2017) in Hong Kong, and Chuchu, Chinomona and Pamacheche (2016) in South Africa. It is worth noting that the aforesaid previous studies have inherent conceptual and methodological limitations. For instance, studies conducted by Kim and Karpova (2010) and Liao et al. (2010) relied on the theory of planned behaviour (TPB), which is known to predict an average of $32 \%-39 \%$ in behavioural intention (Armitage \& Conner 2001).

Similarly, a study conducted by Xi and Cheng (2017) drew variables from the theory of reasoned action, which is known to exclude other factors that have the potential to explain behavioural intention, such as perceived behavioural control (PBC; Ajzen 1991). In addition, Dai and Chen (2017) and Chuchu et al. (2016) utilised a student sample. A germane concern regarding the use of a student sample is that such respondents often lack the purchasing power to make purchase decisions, and this limits the generalisation of research findings.

It is also important to note that most of the previous studies on counterfeit products have predominantly focused on the supply side (e.g. Chaudhry \& Zimmerman 2008; Meraviglia 2018) with fewer efforts devoted to examine factors influencing willingness to purchase such goods from a demand-side perspective. This concern was also raised by Swami et al. (2009). The demand side is regarded as a key pull factor in the counterfeit market (Bian \& Moutinho 2011). To have a detailed appreciation of drivers of counterfeiting behaviour, Bian and Moutinho (2011) urge marketers to strive to understand the key factors that stimulate consumers to buy counterfeit products. Hence, it is high time to examine factors that influence consumers' willingness to purchase counterfeit sportswear.

The findings of this study have the potential to assist marketers, national governments and manufacturers to stem out the tide of counterfeit behaviour beyond the current body of knowledge. In particular, this study sets out to answer the following question: 'What are the rational and normative 
factors influencing consumers' willingness to purchase counterfeit products?' By answering this question, this study seeks to contribute to efforts to curb the growing menace of counterfeit products in the sportswear industry by examining antecedents of consumer attitudes towards counterfeit sportswear and ascertain whether consumer attitudes predict consumers' willingness to buy counterfeit sportswear. The next section discusses the literature on counterfeit and supporting theories, followed by the presentation of the research model and study hypotheses. Thereafter, the research methodology and study findings follow. The last sections include the discussion of results, limitations of the study, recommendations and conclusion.

\section{Literature review}

\section{Underpinning theory and conceptual framework}

Counterfeiting has an ancient history transcending decades (Ting et al. 2016). In its initial phase, it involved the faking of currencies and later evolved to the current predominant form, that is, the imitation of luxury goods (Phillips 2007; Thaichon \& Quach 2016; Wilcox, Kim \& Sen 2009). This has resulted in top global brands such as Rolex, Hermes and Polo becoming prime targets (Ting et al. 2016). The growth of sports economy and the globalisation of sporting codes, such as rugby, soccer and cricket, have also seen growth in counterfeits of leading sportswear brands such as Nike, Adidas and Puma (Perumal \& Sapihan 2017).

Consumer demand is one of the key drivers for the growth and sustenance of counterfeiting behaviour (Bian \& Moutinho 2011). For this reason, Perumal and Sapihan (2017) underscored the importance of understanding factors that influence consumers to prefer counterfeits over genuine products. In this regard, rational models such as the theory of reasoned action (Fishbein \& Ajzen 1975) and TPB (Ajzen 1991) have been used widely. Rational models are considered appropriate to predict determinants of non-deceptive counterfeiting (Kim \& Karpova 2010). This is because consumers knowingly buy counterfeit products, making the behaviour of interest somewhat intentional.

The theory of planned behaviour, which is an extended version of Fishbein and Ajzen's (1975) theory of reasoned action, was postulated by Ajzen in 1991. The TPB was used to predict purchase of pirated software (Liao et al. 2010), online piracy (Penz \& Stottinger 2008), fashion counterfeits (Kim \& Karpova 2010) and sporting goods (Chiu, Lee \& Won 2014). The TPB argues that intention is the most immediate predictor of behaviour (Ajzen 1991). It further suggests that intention is directly influenced by attitude towards behaviour, subjective norm and perceived behavioural control (Ajzen 1991). The TPB posits that behaviour occurs when an individual develops a favourable attitude towards a specific behaviour, perceives that performing such behaviour is necessary as others are doing it and believes in their own abilities to engage in such behaviour (Ajzen 1991). The TPB also postulates direct relationships between attitudes towards behaviour, subjective norm and perceived behavioural control. The TPB is shown in Figure 1.

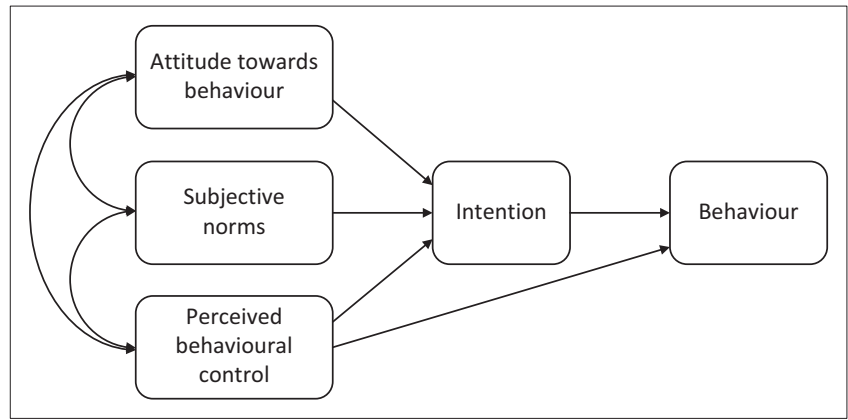

Source: Ajzen, I., 1991, 'The theory of planned behaviour', Organisational Behaviour and Human Decision Processes 50(2), 179-211. https://doi.org/10.1016/0749- 5978(91)90020-T FIGURE 1: Theory of planned behaviour.

Notwithstanding its wide application in predicting counterfeiting behaviour, the TPB has inherent limitations that the current research seeks to address. One of the notable criticisms of the TPB is centred on its proposition that intention is the immediate determinant of behaviour (Sarkis 2017). This criticism is supported by the findings of several studies that found that individuals do not always behave in line with their stated intentions (Gerrard et al. 2008; Ohtomo \& Ohnuma 2014; Sopha 2013). The attitude-intentionbehaviour gap has been widely reported in studies that have used TPB (Carrigan, Moraes \& Leek 2011; Papaoikonomou, Ryan \& Valverde 2012). This gap is manifested when individuals who report a favourable attitude and intention towards a particular behaviour fail to engage in the behaviour (Yeow, Dean \& Tucker 2014). Another weakness that has been attributed to the TPB is its assumption that behaviour is planned and intentional.

With regard to counterfeit products, Gerrard et al. (2008) argue that the consumption of counterfeits may be impulsive and non-intentional. For this reason, this study follows the example of researchers such as Gerrard et al. (2008), Gibbons, Houlihan and Gerrard (2009) and Ohtomo and Ohnuma (2014) who used the behavioural willingness construct. For socially undesirable behaviours, of which counterfeiting is one, willingness was found to be more apt in predicting behaviour than intention (Gerrard et al. 2008; Gibbons et al. 2009). Because of the illicit nature of counterfeiting behaviour, $\mathrm{Xi}$ and Cheng (2017) note the operational challenge of measuring actual purchase behaviour. Because of the foregoing, willingness to purchase counterfeits was used in this study as a proxy of actual behaviour.

There are also concerns on how the perceived behaviour control is operationalised within the TPB (Davies, Foxall \& Pallister 2002). The perceived behaviour control measures an individual's control beliefs to engage in behaviour (Ajzen 2002; Londono, Davies \& Elms 2017). Apart from the perceptions of easiness or difficulties of performing behaviour, the theory of interpersonal behaviour (Triandis 1977) also considers the influence of the existence or nonexistence of facilitating conditions such as the availability of resources such as time and money. In developing economies such as South Africa, the purchase of counterfeit products is regarded as an economic issue (Cant et al. 2014). Thus, this 
study also considers the influence of perceived financial control. The addition of perceived financial control finds support from Ajzen's (1991) view that the TPB is open to inclusion of other variables that have the potential to increase its explanatory power.

Based on the foregoing discussion and consistent with the $\mathrm{TPB}$, the proposed conceptual model of this study posits that perceived behavioural control, subjective norm and perceived financial control directly influence attitude towards counterfeits. In turn, attitude towards counterfeits is expected to influence willingness to purchase counterfeit products. Based on the findings of study conducted by Gibbons et al. (1998) that willingness is more apt to predict behaviour of socially undesirable acts, willingness to purchase counterfeits rather than purchase intention is considered in this study. Figure 2 shows the conceptual framework underpinning this study.

\section{Development of hypotheses}

Based on the structural relationships shown in Figure 2, the following section discusses the hypothesised relationships between variables under investigation.

\section{Perceived behavioural control}

The TPB posits a direct relationship between perceived behavioural control and attitude towards behaviour (Ajzen 1991). In the context of this study, perceived behavioural control evaluates the extent to which consumers experience challenges in the process of buying counterfeit sportswear products. Across counterfeit markets, as noted by Londono et al. (2017), the magnitude of counterfeiting behaviour depends on the existence and extent of enforcement of anticounterfeiting laws. Counterfeiting behaviour tends to flourish if it is easy to do and aided by facilitating conditions such as availability of counterfeits and convenience (Cheng et al. 2011). When consumers perceive higher levels of perceived behavioural control, this triggers the formation of favourable attitudes (Londono et al. 2017). Perceived behavioural control is conceptually tied to the cognitive attitudinal component, which involves a rational assessment of the feasibility of engaging in specific behaviours (Ajzen 1991). Consistent with the foregoing discussion, following hypothesis was put forward:

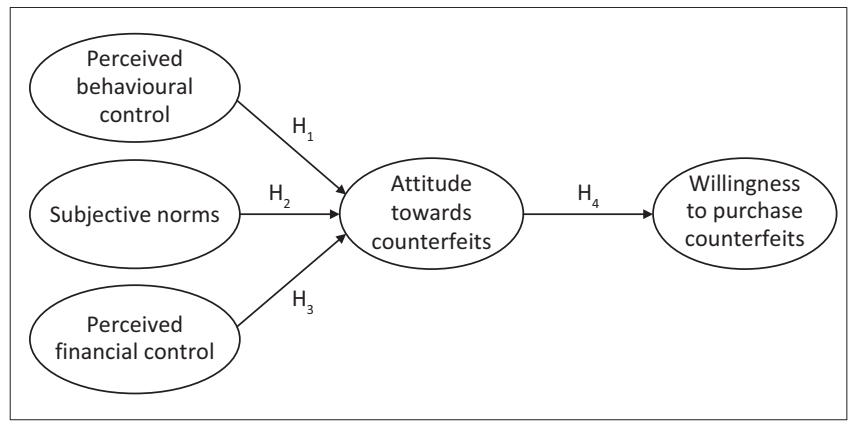

FIGURE 2: Conceptual model.
$\mathbf{H}_{1}$ : Perceived behavioural control positively influences consumer
attitudes towards counterfeit sportswear.

\section{Subjective norm}

Subjective norm denotes the social influence exerted on an individual's decision-making process by close associates (Phau \& Teah 2009). In South Africa, anti-counterfeiting laws and coercive measures such as seizures are failing to address the scourge of counterfeits (Cant et al. 2014). Thus, if societal norms are known, they may act as a potent weapon to address the counterfeiting problem. Ahmed (2016) argues that counterfeiting behaviour is usually embedded within an individual's cultural setting. This is because, as noted by Kish-Gephart, Harrison and Trevino (2010), the purchase and consumption of counterfeit products are perceived as unethical behaviour that infringes on cherished societal values and norms. Subjective norm acknowledges the role of family, friends and opinion leaders as socialisation agents with a significant influence on the purchase decisions of their acquaintances (Chew \& Leng 2014). For this reason, Cant et al. (2014) regard counterfeiting behaviour as a social issue.

Subjective norm is linked to attitudes through the affective component, a quest for affiliation and acceptance by key referents (Schiffman, Kanuk \& Wisenblit 2010). The TPB predicts a direct relationship between subjective norm and attitude (Ajzen 1991). According to Chiu and Leng (2016), when consumers think that their significant others (friends and family) align their beliefs with the purchase of counterfeit products, there is a likelihood that they develop favourable attitudes towards counterfeits. The consumption of sport and other fitness activities is a group activity and subjective norm is anticipated to have a positive effect on attitudes towards counterfeit sportswear products. Hence, the following hypothesis was formulated:

$\mathbf{H}_{2}$ : Subjective norm positively influences attitudes towards counterfeit sportswear.

\section{Perceived financial control}

Perceived financial control considers the financial capability of consumers when buying counterfeit products (Adhikari \& Biswakarma 2017; Cheng et al. 2011). An understanding of consumers' perceptions of financial control is important for manufacturers of counterfeited brands and regulators to know whether price is one of the driving factors. The use of counterfeits was found to transcend social class (Cheng et al. 2011).

Previous research conducted by Sahni (1994) modified TPB by replacing perceived behavioural control with perceived financial control in the prediction of purchase intentions. This was based on the premise that financial capability of consumers plays a central role predicting purchase intentions. Based on the literature reviewed and previous studies, the following hypothesis was formulated:

$\mathbf{H}_{3}$ : Perceived financial control positively impacts on consumer attitudes towards counterfeit sportswear. 


\section{Attitude towards counterfeits}

Attitude is a learned disposition which directs an individual to respond either favourably or unfavourably to a given situation (Chiu et al. 2014). When consumers develop favourable attitudes towards the acquisition and consumption of counterfeits, there is a possibility that they will buy such products (Chiu \& Leng 2016). With regard to consumers' attitude towards counterfeit purchase, consumers assess such products based on quality and look-alike features (Cheng et al. 2011). During this information-processing stage, customers disregard negative personal feelings, such as shame or guilt associated with buying counterfeit products (Penz \& Stottinger 2005). Willingness to purchase refers to the consumers' inclination to perform a given behaviour (Gerrard et al. 2008). Willingness to purchase is significantly influenced by the prevalence of favourable attitudes towards the behaviour of interest (Cheng et al. 2011). Specific to counterfeit products, studies have established a positive association between attitude towards counterfeits and willingness to buy such products (Chiu et al. 2014; Swami et al. 2009; Wee et al. 1995). Based on the foregoing arguments, the following hypothesis was formed:

$\mathbf{H}_{4}$ : Attitudes towards counterfeits positively influence consumers' willingness to purchase counterfeit sportswear.

\section{Willingness to purchase counterfeits}

Willingness and intention to purchase are two different terms that are linked closely. In empirical studies, intention is commonly used to explain planned behaviour (Ajzen \& Fishbein 1975). Conversely, willingness refers to the unintentional motivation that is prompted by conditions ideal for impulsive or spontaneous behaviour, notwithstanding one's intention (Gibbons et al. 2009). This study uses the willingness to purchase construct because the purchase of counterfeits, as observed by Gerrard et al. (2008), follows the non-intentional route. This reasoning seems relevant for the purchase of counterfeit sportswear which tends to be spontaneous during the staging of major sporting events. Because of the challenges associated with the collection of data related to the actual sales of counterfeit products, as noted by Gibbons et al. (2009) and Perumal and Sapihan (2017), willingness to purchase counterfeits was used in this study to assess the readiness of consumers to purchase counterfeit sportswear products.

\section{Research methods and design Study design}

The study was grounded within the post-positivist research philosophy. A descriptive research was followed because the overriding objective of this study was to examine factors that influence counterfeiting behaviour.

\section{Setting of the study}

This study investigated consumer attitudes and willingness to purchase counterfeits of three top established sportswear brands, which included Adidas, Nike and Puma. The study focused on five sportswear items, which included replica jerseys, jackets, t-shirts, caps/hats and footwear. Participants were recruited from South Africa's southern Gauteng region and Johannesburg central business district. The selling of counterfeit sportswear is rife in these areas based on the frequency of seizures of such products.

\section{Study population and sampling strategy}

There was no sample frame for this study which rendered the use of probability sampling methods impossible. Two approaches were used to determine sample size. The rule of thumb suggested by Hair et al. (2013) of having five responses for each questionnaire item was used as a benchmark to determine the minimum sample size threshold. The questionnaire utilised in this study comprised 33 questionnaire items, which translated to a minimum sample size of 165 . Consideration for the maximum sample size was informed by the historical evidence method. The historical evidence method determines sample size by benchmarking against previous related studies (Zikmund \& Babin 2010). In line with past similar studies conducted by Ha and Lennon (2006), Sondhi (2017), Xi and Cheng (2017) and Hashim, Shah and Omar (2018), a sample size ranging from 200 to 395 respondents was considered adequate. Consistent with the aforesaid sample benchmarks, this study utilised a sample size of 390 respondents to understand consumer attitudes and willingness to purchase counterfeit sportswear products.

\section{Data collection}

Prior to fieldwork, the questionnaire was assessed by experts in consumer studies for content validity and pre-tested to determine the time frame for completion and identify the problems related to scale items (Zikmund \& Babin 2010). Following the pre-test, minor adjustments were effected. Measurement scale items were scored on a five-point scale ( 1 = strongly disagree to $5=$ strongly agree). Because of the illicit nature and sensitivity of counterfeit purchase behaviour, data collection was performed using the convenience sampling approach using the mall-intercept technique. The mall-intercept technique proved to be effective in previous studies on counterfeit (Hashim et al. 2018; Perumal \& Sapihan 2017). Respondents were recruited from 11 retail outlets known for selling counterfeit sportswear. The identified consumers were approached and requested to complete a structured questionnaire.

\section{Measurement instrument}

All variables under investigation were operationalised using validated scales from previous related studies.

Perceived behavioural control was measured with a sevenitem scale adapted from Chiu and Leng (2016:25) and Cheng et al. (2011:283). Some of the items used include 'buying counterfeit sporting goods is entirely within my control' and 'I have enough information to access counterfeit sporting products'. Subjective norms were measured with a five-item 
scale adapted from Chiu and Leng (2016:25). Some of the items utilised are the following: 'If I purchase counterfeit sporting goods, most of the people who are important to me will approve' and 'People who are important to me will look down on me if I purchase counterfeit sporting goods'. Perceived financial control was measured using a three-item scale adapted from Cheng et al. (2011:283). Examples of scale items used are the following: 'I could likely afford to pay such a price for purchasing original products' and 'My personal income permits me to easily spend money for original products'.

Attitude towards counterfeit sportswear was measured using a five-item scale adapted from Haung, Lee and Ho (2004:614). Some of the scale items include 'Generally speaking, counterfeits have a satisfying quality' and 'For me, buying counterfeits is virtue of thrift'. Finally, willingness to purchase counterfeit sportswear was measured with a six-item scale adapted from Beck and Ajzen (1990:290). Examples of scale items used include 'There is a high likelihood, I would consider counterfeits when making a purchase' and 'I would consider buying counterfeit sporting goods in the future'.

\section{Ethical considerations}

The purpose of the study was explained to respondents with the aid of a cover letter. All respondents voluntarily participated and no incentives were offered. Respondent anonymity and confidentiality was safeguarded.

\section{Results}

\section{Sample composition}

A total of 390 valid responses were received. Male participants constituted 55\% $(n=216)$ and females constituted $44 \%(n=174)$ of the sample. Thirty-nine per cent $(n=152)$ purchased footwear, 26.9\% $(n=105)$ t-shirts, $24.1 \%(n=94)$ replica jerseys and $10 \%(n=39)$ jackets. The majority of participants were between 25 and 32 years of age $(46.9 .1 \% ; n=183)$, followed by $33-40$ years of age $(21.5 \% ; n=84)$ and $41-48$ years of age $(19.5 \% ; n=76)$. The majority of participants earned a monthly income of R10 $000-15000(36,9 \% ; n=144)$, followed by below R15 $000(24.1 \% ; n=94)$ and R15 $001-20000(24.1 \% ; n=71)$. Finally, in terms of education levels, the majority were in possession of a matric certificate $(45.9 \% ; n=179)$ followed by holders of a diploma or degree $(35.1 \% ; n=137)$.

\section{Common method variance}

Cross-sectional studies relying on self-reported data are prone to common method bias (CMB) (Podsakoff, MacKenzie, Lee \& Podsakoff 2003). Common method bias refers to the variation in study findings that emanate from the measurement method utilised in a given study (Krishnaveni \& Deepa 2013). Common method bias was assessed using Harman's single factor test. The highest single factor from unrotated factor analysis was 20.653\%, which is far less than 50\% (Gaskin 2011), signifying the absence of $\mathrm{CMB}$ in this study.

\section{Descriptive statistics, reliability and validity of study constructs}

The internal consistency of measurement items was checked using Cronbach's alpha coefficient. Descriptive statistics and Cronbach's alpha values of study constructs are shown in Table 1.

In terms of the mean values, consumers were non-committal $(M=3.1)$ regarding their perceptions of perceived behavioural control. However, with regard to subjective norms $(M=4.04)$, perceived financial control $(M=3.90)$, attitudes towards counterfeit $(M=3.90)$ and willingness to purchase counterfeits $(M=4.3)$, consumers were more inclined to agree that these constructs play a role in the purchase of counterfeits. As shown in Table 1, Cronbach's alpha values for all scales ranged from 0.714 to 0.94 , surpassing the recommended minimum value of 0.70 (Malhotra 2010). Also, item-total correlations of all scale items were above 0.5 , signifying the attainment of convergent validity (Pallant 2011).

\section{Correlational analysis}

The strength and direction of association between the study constructs (perceived behavioural control, perceived financial control, attitudes and willingness to purchase counterfeits) were assessed using Pearson Product Moment. Table 2 shows results of the correlational analysis.

TABLE 1: Descriptive statistics and reliability of study constructs.

\begin{tabular}{|c|c|c|c|c|c|c|}
\hline Constructs & $\begin{array}{l}\text { Scale } \\
\text { items }\end{array}$ & $\begin{array}{l}\text { Item total } \\
\text { correlation }\end{array}$ & $\begin{array}{l}\text { Squared multiple } \\
\text { correlations }\end{array}$ & $\begin{array}{l}\text { Cronbach's } \\
\text { alpha }\end{array}$ & Mean & $\begin{array}{l}\text { Standard } \\
\text { deviation }\end{array}$ \\
\hline \multirow{7}{*}{$\begin{array}{l}\text { Perceived } \\
\text { behavioural } \\
\text { control (PBC) }\end{array}$} & PBC1 & 0.821 & 0.840 & \multirow[t]{7}{*}{0.949} & \multirow[t]{7}{*}{3.1} & \multirow[t]{7}{*}{0.949} \\
\hline & PBC2 & 0.882 & 0.884 & & & \\
\hline & PBC3 & 0.804 & 0.831 & & & \\
\hline & PBC4 & 0.817 & 0.694 & & & \\
\hline & PBC5 & 0.817 & 0.843 & & & \\
\hline & PBC6 & 0.845 & 0.860 & & & \\
\hline & PBC7 & 0.810 & 0.838 & & & \\
\hline \multirow{5}{*}{$\begin{array}{l}\text { Subjective } \\
\text { norm (SN) }\end{array}$} & SN1 & 0.614 & 0.460 & \multirow[t]{5}{*}{0.809} & \multirow[t]{5}{*}{4.04} & \multirow[t]{5}{*}{0.598} \\
\hline & SN2 & 0.566 & 0.518 & & & \\
\hline & SN3 & 0.601 & 0.409 & & & \\
\hline & SN4 & 0.648 & 0.569 & & & \\
\hline & SN5 & 0.569 & 0.414 & & & \\
\hline \multirow{9}{*}{$\begin{array}{l}\text { Attitude } \\
\text { towards } \\
\text { counterfeit } \\
\text { sportswear } \\
\text { (ATT) }\end{array}$} & ATT1 & 0.790 & 0.834 & \multirow[t]{9}{*}{0.775} & \multirow[t]{9}{*}{3.9} & \multirow[t]{9}{*}{0.689} \\
\hline & ATT2 & 0.550 & 0.469 & & & \\
\hline & ATT3 & 0.575 & 0.483 & & & \\
\hline & ATT4 & 0.580 & 0.448 & & & \\
\hline & ATT5 & 0.575 & 0.405 & & & \\
\hline & ATT6 & 0.579 & 0.505 & & & \\
\hline & ATT7 & 0.646 & 0.503 & & & \\
\hline & ATT8 & 0.531 & 0.443 & & & \\
\hline & ATT9 & 0.530 & 0.453 & & & \\
\hline \multirow{3}{*}{$\begin{array}{l}\text { Perceived } \\
\text { financial } \\
\text { control (PFC) }\end{array}$} & PFC1 & 0.587 & 0.351 & \multirow[t]{3}{*}{0.714} & \multirow[t]{3}{*}{3.9} & \multirow[t]{3}{*}{0.686} \\
\hline & PFC2 & 0.549 & 0.327 & & & \\
\hline & PFC3 & 0.508 & 0.343 & & & \\
\hline \multirow{6}{*}{$\begin{array}{l}\text { Willingness } \\
\text { to purchase } \\
\text { (WTP) }\end{array}$} & WTP1 & 0.581 & 0.527 & \multirow[t]{6}{*}{0.846} & \multirow[t]{6}{*}{4.3} & \multirow[t]{6}{*}{0.620} \\
\hline & WTP2 & 0.751 & 0.625 & & & \\
\hline & WTP3 & 0.611 & 0.538 & & & \\
\hline & WTP4 & 0.604 & 0.511 & & & \\
\hline & WTP5 & 0.452 & 0.386 & & & \\
\hline & WTP6 & 0.775 & 0.681 & & & \\
\hline
\end{tabular}


As shown in Table 2, there was a significant positive relationship between all variables with the coefficients ranging from moderate $(r=0.330 ; p<0.01)$ to strong relationships $(r=0.696)$. Also, the highest correlation coefficient is between perceived financial control and attitude towards counterfeit $(r=0.696 ; p<0.01)$, indicating the absence of multicollinearity (Pallant 2011). Multicollinearity exists when variables are highly correlated with coefficients $(r)$ of above -8.00 or 8.00 (Grewal, Cote \& Baumgartner 2004). The absence of multicollinearity signifies the distinctiveness of variables in this study, which shows evidence of discriminant validity.

\section{Regression analysis}

The hypothesised relationships between variables were tested using standard multiple standard regression analysis. This statistical technique is recommended for examining linear interrelationships between variables (Pallant 2011), which was the objective of this study. Structural equation modelling was not used in this study because it is more suitable for validating and testing complex measurement and structural models (McQuitty \& Wolf 2013). The first step involved assessing the attainment of conditions required to conduct regression analysis. Inspection of the correlation matrix showed absence of multicollinearity. The sample size of 390 was adequate as it surpassed Tabachnick and Fidell's (2007) minimum threshold of $N>50+8 m$ (where $m$ denotes the number of independent variables, which were four in this study). Moreover, the tolerance statistics for predictor variables ranged from 1.000 to 0.988 , whilst the variance inflation factor (VIF) was below 10, indicating that there were no collinearity issues within the data set (Field 2009).

Standard multiple regression analysis was conducted in two stages. Firstly, model 1 examined the relationship between perceived behavioural control, perceived financial control and subjective norms with attitudes towards counterfeits. The second stage (model 2) involved examining the

TABLE 2: Correlations of study constructs.

\begin{tabular}{lccccc}
\hline Constructs & PBC & PFC & SN & ATT & WTP \\
\hline Perceived behavioural control (PBC) & - & - & - & - & - \\
Perceived financial control (PFC) & 0.076 & - & - & - & - \\
Subjective norms (SN) & 0.063 & $0.638^{*}$ & - & - & - \\
Attitudes towards counterfeit (ATT) & 0.055 & $0.696 *$ & $0.470 *$ & - & - \\
Willingness to purchase (WTP) & 0.041 & $0.543^{*}$ & $0.330^{*}$ & $0.622^{*}$ & - \\
\hline
\end{tabular}

*, Correlations are significant at $p<0.01$.

TABLE 3: Regression analysis results.

\begin{tabular}{lccccc}
\hline Study constructs & Beta & $\boldsymbol{t}$ & Sig. & Tol. & VIF \\
\hline Model 1: Dependent variable (attitude [ATT]) & & & & \\
Perceived behavioural control (PBC) & 0.005 & 0.0960 & 0.636 & 0.988 & 1.228 \\
Subjective norms (SN) & 0.296 & 4.2180 & $0.000 *$ & 0.788 & 1.578 \\
Perceived financial control (PFC) & 0.902 & 18.4200 & $0.000^{*}$ & 0.780 & 1.660 \\
Model 2: Dependent variable (willingness to purchase, [WTP]) & & \\
Attitude towards counterfeits (ATT) & 0.823 & 18.0200 & $0.000^{*}$ & 1.00 & 1.000 \\
\hline
\end{tabular}

Note: Model 1: $R=0.845 ; R^{2}=0.672 ;$ adjusted $R^{2}=0.651$. Model $2: \mathrm{R}=0.753 ; R^{2}=0.533$; adjusted $R^{2}=0.511$.

Tol., tolerance; VIF, variance inflation factor; $t, t$-value.

*, Significant $p<0.01$. relationship between attitudes towards counterfeits and willingness to purchase counterfeits. Table 3 shows the results of regression analysis for models 1 and 2 .

As shown in Table 3, consumers' attitudes towards counterfeit products are largely shaped by subjective norms and perceived financial control. Perceived financial control was the major predictor of attitudes towards counterfeits, followed by subjective norms. Approximately $67 \%$ of the variation in attitudes towards sportswear counterfeits is primarily predicted by subjective norms and perceived financial control.

In turn, approximately $53 \%$ of the variance in consumers' willingness to purchase counterfeits is predicted by consumers' attitude towards counterfeits.

\section{Discussion}

The findings of the study revealed an insignificant effect of perceived behavioural control on consumer attitude towards counterfeit sportswear $(t=0.0960 ; p<0.636)$, disconfirming H1. This result suggests that consumers surveyed in this study did not perceive constraints when buying counterfeit sportswear. This finding is in line with past studies by Alam et al. (2011) and Perumal and Sapihan (2017), in which perceived behaviour was found to have an insignificant effect on purchase intentions of pirated software and sportswear respectively. In cases where societal norms are favourably inclined towards a specific behaviour, Armitage and Conner (2001) note that collective efficacy enhances the easiness of engaging in the behaviour of interest. In this study, the path coefficient from subjective norms to attitude towards counterfeit sporting goods is positive and significant, which may have consequently led to perceived behavioural control being less predictive of consumers' attitudes towards counterfeit sportswear. A further plausible reason for an insignificant relationship between these two constructs could be attributed to the less stringent law enforcement within a South African context where consumers can easily purchase counterfeit sportswear products.

The study found that subjective norm has a positive significant effect on consumer attitudes towards counterfeit sportswear $(t=4.2180 ; p<0.01)$, thereby supporting H2. The results are supported by previous studies that showed positive associations between subjective norms and attitudes towards counterfeit products (Phau \& Teah 2009; Tang, Tian \& Zaichkowsky 2014; Thaichon \& Quach 2016). For instance, a study by Thaichon and Quach (2016) found that respondents were not embarrassed to be seen by key referents buying counterfeit products. Conversely, Tang et al. (2014) found that fear of disapproval by close associates may restrain an individual consumer from buying counterfeit products (Tang et al. 2014). In the same vein, Chiu and Leng (2016) note that the influence of subjective norms on consumers' attitudes and willingness to buy counterfeit products also depends on quality. In essence, Chiu and Leng (2016) observed that counterfeit products of low quality could easily be noticed, which triggers disapproval from an individual's social 
network. This was observed regarding counterfeits of the Prada brand coined Prado.

Overall, subjective norms have the effect of moral licensing, thereby entrenching detrimental behaviours.

Perceived financial control had the strongest effect on consumer attitudes towards counterfeit sportswear products $(t=18.4200 ; p<0.01)$, lending support to H3. This result resonates with that of past studies (Poddar et al. 2012; Thaichon \& Quach 2016; Wang \& Song 2013). For instance, in a study performed by Wang and Song (2013), consumers were motivated by cost savings, and by affordability in a study conducted by Thaichon and Quach (2016). This result lends further support to the long-held view that price plays a pivotal role in influencing counterfeit purchase decisions (Wang \& Song 2013). This is particularly the case in the context of developing economies such as South Africa where discretionary disposable incomes are low. Apart from cost savings, Wang and Song (2013) also urge that the purchase of counterfeit products may be a form of consumer protest against unaffordable and premium-priced genuine brands. To enhance affordability, Ting et al. (2016) suggest that manufacturers of counterfeited brands may consider introducing affordable brand extensions in a manner that does not dilute brand image. This may enable the brand to appeal to both high- and low-income consumer segments.

Attitude towards counterfeit sportswear was found to have a significant positive effect on willingness to purchase counterfeits $(t=18.0200 ; p<0.01)$, thereby confirming H4. This result resonates with the findings of previous studies confirming that attitudes towards counterfeits influence consumers' purchase intention of counterfeit products (Penz \& Stottinger 2005; Xi \& Cheng 2017). This result points to the need by marketers of counterfeit products to change procounterfeit attitudes. This, according to Cheung and Prendegast (2006), could be carried out by introducing loyalty programmes that reward consumers who buy genuine sportswear products. In addition, consumer education emphasising the negative economic effects of counterfeit could, according to Phau and Teah (2009), be a potent tool to change pro-counterfeit consumer attitudes.

\section{Limitations of the study}

This study relied on self-reported data to test the proposed models. There is a possibility that some respondents may have inflated or understated the extent of their counterfeiting behaviour. The future studies could address this weakness by using data collection methods such as observation to reduce incidences of social desirability bias. This study was confined to two geographical areas, southern Gauteng and Johannesburg central business district. This, therefore, limits the generalisation of this study. The future studies could extend this study to other geographical areas such as Durban and Cape Town with ports of entry commonly used to ship in counterfeit products. Furthermore, the study was conducted through a mall intercept type of survey (convenience) which necessitates further investigation through various data collection techniques such as observation and online platforms. The current research is insufficient to unanimously distinguish the factors that could influence consumer intent to purchase counterfeits. Further research is necessitated wherein other variables such as the influence of perceived risk, ethics and good citizenship could be examined.

\section{Theoretical and managerial implications}

This study contributed to theory by proposing a modified TPB which managed to explain a significant variance in attitudes towards counterfeit of $67 \%$. This is far more than the average of $31 \%-39 \%$ reported in TPB meta-analysis studies for self-reported data (Armitage \& Conner 2001).

Nonetheless, further research could examine other factors that potentially explain the variance in attitudes towards counterfeit products that was not captured in this study. The findings of this study also offer valuable insights to manufacturers and marketers of genuine sportswear as well as regulatory authorities. Perceived financial control and subjective norms emerged as the main factors influencing favourable attitudes towards counterfeit sportswear products. Manufacturers and marketers of genuine counterfeit sportswear products may consider making original products more affordable through the introduction of brand extensions and targeted licensing. According to Ting et al. (2016), this could be carried out in a way that does not dilute brand equity (Ting et al. 2016). This strategy proved to be successful for Calvin Klein when it extended its CK brand (Phau \& Teah 2009).

There is also an urgent need to educate consumers about the social and economic downside of buying counterfeit products. In this regard, Thaichon and Quach (2016) recommended the use of moral suasion and celebrity endorsements. $\mathrm{Xi}$ and Cheng (2017) also emphasise the importance of creating purchase experiences that negate counterfeiting behaviour. This could be conducted by rewarding, through loyalty programmes, consumers who buy genuine products. The finding of this study, which indicated that consumers perceived limited constraints when purchasing counterfeit sportswear products, should be a great concern for South Africa's regulatory authorities. This result points to the need to strengthen the enforcement of anti-counterfeit laws. In addition, moral suasion could be used to create awareness of danger of buying and consuming counterfeit goods.

\section{Conclusion}

This study sought to generate some insights into nondeceptive counterfeiting using the modified TPB. Subjective norms and perceived financial control emerged as major factors that drive favourable attitudes towards counterfeit sportswear. The study notes that laws and coercive measures such as seizures are not adequate in solving the problem of counterfeiting. The study points to the need for the 
implementation of behavioural change strategies. In this regard, the study recommends the use of normative and rational strategies to educate consumers about the economic downside of counterfeit products. Because consumers are enticed by cheaper prices to buy counterfeit sportswear, marketers could consider using nudges such as rewards and subsidies to encourage the purchase of genuine products. There is also a need for the South African government to effectively enforce anti-counterfeiting laws accompanied by deterrent fines for fake designers and sellers. To develop a comprehensive understanding of the evolving nature of counterfeiting behaviour, there is a need to also consider the influence of other variables such as ethical judgements, role of anticipated emotions, perceived risk and material culture.

\section{Acknowledgements}

The authors thank the reviewers for their constructive comments that helped improve the quality of this article.

\section{Competing interests}

The authors declare that they have no competing interests and no financial or personal relationships that may have inappropriately influenced them in writing this article.

\section{Authors' contributions}

M.D. conceptualised the study, and conducted literature review, data collection and analysis. A.M. was responsible for literature review, data collection and article submission.

\section{Funding information}

The authors thank Vaal University of Technology for funding this study.

\section{Data availability statement}

The data will be made available upon request.

\section{Disclaimer}

The views expressed in this article are those of the authors and do not represent an official position of the institution or the funder.

\section{References}

Abraham, J., Takwin, B. \& Suleeman, J., 2018, 'Counterfeit self: A confirmatory factor analysis among Indonesians', Kasetsart Journal of Social Sciences 39(3), 518-525. https://doi.org/10.1016/j.kjss.2017.07.011

Adhikari, H. \& Biswakarma, G., 2017, 'Determinants of purchase intention towards counterfeit apparels in Nepalese consumers', International Journal of Research in Business Studies and Management 4(10), 10-17.

Ahmed, A., 2016, 'Countering counterfeiting branding: Implications for public sector marketing', Journal of Non-Profit \& Public Sector Marketing 28(3), 273-286. https://doi.org/10.1080/10495142.2016.1206503

Ajzen, I., 1991, 'The theory of planned behaviour', Organisational Behaviour and Human Decision Processes 50(2), 179-211. https://doi.org/10.1016/07495978(91)90020-T

Ajzen, I., 2002, 'Perceived behavioural control, self-efficacy, locus of control and the theory of planned behaviour', Journal of Applied Social Psychology 32(4), 665-683. https://doi.org/10.1111/j.1559-1816.2002.tb00236.x
Ajzen, I. \& Fishbein, M., 1980, Understanding attitudes and predicting social behaviour, Prentice Hall, Englewood Cliffs, NJ.

Alam, S., Ahmad, A., Ahmad, M. \& Hashim, N., 2011, 'An empirical study of an extended theory of planned behaviour model for pirated software purchase', World Journal of Management 3(1), 124-133.

Armitage, C.L. \& Conner, M., 2001, 'Efficacy of the theory of planned behaviour. A meta-analytic review', British Journal of Social Psychology 40, 471-499. https:// doi.org/10.1348/014466601164939

Beck, L. \& Ajzen, I., 1990, 'Predicting dishonest actions using the theory of planned behaviour', Journal of Research in Personality 25(3), 285-301. https://doi. org/10.1016/0092-6566(91)90021-H

Bian, X. \& Moutinho, L., 2011, 'The role of brand image, product involvement, and knowledge in explaining consumer purchase behaviour of counterfeits: Direct and indirect effects', European Journal of Marketing 45(1/2), 191-216. https://doi. indirect effects', European Journal
org/10.1108/03090561111095658

Cant, M.C., Wiid, J.A. \& Manley, L.L., 2014, 'Counterfeit luxury fashion brands: Consumer purchase behaviour', Corporate Ownership \& Control 11(3), 175-183. https://doi.org/10.22495/cocv11i3c1p4

Carrigan, M., Moraes, C. \& Leek, S., 2011, 'Fostering responsible communities: A community social marketing approach to sustainable living', Journal of Business Ethics 100, 515-534. https://doi.org/10.1007/s10551-010-0694-8

Chaudhry, P.E. \& Zimmerman, A., 2008, The economics of counterfeit trade: Governments, consumers, pirates and intellectual property rights, Springer, Berlin. https://doi.org/10.1007/978-3-540-77835-6

Cheng, S.I., Fu, H. \& Tu, L.T.C., 2011, 'Examining customer purchase intentions for counterfeit products based on a modified theory of planned behaviour', International Journal of Humanities and Social Science 35(1), 41-53.

Cheung, W.L. \& Prendergast, G., 2006, 'Buyers' perceptions of pirated products in China', Marketing Intelligence \& Planning 24(5), 446-462. https://doi. org/10.1108/02634500610682854

Chew, S.S. \& Leng, H.K., 2014, 'Marketing sports products on Facebook: The effect of social influence', Physical Culture and Sport Studies and Research 61(10), 65-73. https://doi.org/10.2478/pcssr-2014-0006

Chiu, W., Lee, K.-Y. \& Won, D., 2014, 'Consumer behaviour towards counterfeit sporting goods', Social Behaviour and Personality 42(4), 615-624. https://doi. org/10.1108/APJML-02-2015-0031

Chiu, W. \& Leng, H.K., 2016, 'Consumers' intention to purchase counterfeit sporting goods in Singapore and Taiwan', Asia Pacific Journal of Marketing and Logistics goods in Singap
$28(10), 23-36$.

Chuchu, T., Chinomona, R. \& Pamacheche, R., 2016, 'Factors that influence the purchase of counterfeit products by students: A case of South Africa', in Proceedings of International Conference on Ethics of Business, Economics and Social Science, September 16-17, Yogyakarta State University, Yogyakarta, Social Science, Septem
Indonesia, pp. 324-337.

Dai, X. \& Chen, K., 2017, 'Examining antecedents of brand loyalty on sport wear: An empirical investigation of university students in Hong Kong', International Journa of Social Science Studies 5(7), 87-96. https://doi.org/10.11114/ijsss.v5i7.2459

Darmayanti, D. \& Boediono, M., 2012, 'Factors influencing the intention of consumer purchases of counterfeit branded products in Jakarta', The Business Management Review 3(1), 120-127.

Davies, J., Foxall, G.R. \& Pallister, J., 2002, 'Beyond the intention-behaviour mythology: An integrated model of recycling', Journal of Marketing Theory 2(1), 29-113. https://doi.org/10.1177/1470593102002001645

Field, A., 2009, Discovering statistics using SPSS, 2nd edn., Sage, London.

Fishbein, M. \& Ajzen, I., 1975, Belief, attitude, intention and behaviour: An introduction to theory and research, Addison-Wesley, Reading.

Formosa, N., 2011, 'Brands push to stem flow of fake product', Bicycle Retailer \& Industry News 20(17), 1-33.

Gaskin, J., 2011, 'Common method bias', YouTube, viewed 20 June 2019, from https:// www.youtube.com/watch?v=w7zZCBIRXog.

Gerrard, M., Gibbons, F.X., Houlihan, A.E., Stock, M.L. \& Porney, E.A., 2008, 'A dualprocess approach to health risk decision-making: The proto-type willingness model', Developmental Review 28(1), 29-61. https://doi.org/10.1016/j.dr.2007.10.001

Gibbons, F.X., Gerrard, M., Blanton, H. \& Russell, D.W., 1998, 'Reasoned action and social reaction: Willingness and intention as independent predictors of health risk', Journal of Personality and Social Psychology 74(5),1164-1180. https://doi. org/10.1037/0022-3514.74.5.1164

Gibbons, F.X., Houlihan, A.E. \& Gerrard, M., 2009, 'Reaction and reason: The utility of a dual focus, dual-processing perspective on promotion and prevention of adolescent risk behaviour', Britain Journal of Health Psychology 14, 231-248. https://doi.org/10.1348/135910708X376640

Grewal, R., Cote, J.A. \& Baumgartner, H., 2004, 'Multicollinearity and measurement error in structural equation models: Implications for theory testing', Marketing Science 23(4), 519-529. https://doi.org/10.1287/mksc.1040.0070

Ha, S. \& Lennon, S.J., 2006, 'Purchase intent for fashion counterfeit products: Ethical ideologies, ethical judgements and perceived risks', International Textile \& Apparel Association 4(4), 297-315. https://doi.org/10.1177/0887302X06293068

Hair, J.F., Celsi, M.W., Ortinau, D.J. \& Bush, R.P., 2013, Essentials of marketing research, 4th edn., McGraw Hill Education, Boston, MA.

Haman, M., 2010, 'Africa rising to the anti-counterfeit challenge', Journal of Intellectua Property Law \& Practice 5(5), 344-349. https://doi.org/10.1093/jiplp/jpq024

Hashim, N.M.H.N., Shah, N.U. \& Omar, N.A., 2018, 'Does counterfeit product quality lead to involvement and purchase intentions? The moderating effects of brand image and social interaction', International Journal of Economics and Management 12(2), 607-620. 
Haung, J.-H., Lee, B.C.Y. \& Ho, S.H., 2004, 'Consumer attitude towards gray market goods', International Marketing Review 21(6), 598-614. https://doi. goods', International Marketing

Heike, S., 2010, 'Effects of counterfeits on the image of luxury brands: An empirical study from the consumer perspective', Journal Brand Management 18(2) 159-173. https://doi.org/10.1057/bm.2010.28

Kim, H. \& Karpova, E., 2010, 'Consumer attitudes towards fashion counterfeits: Application of the theory of planned behaviour', Clothing \& Textiles Research Journal 28(2), 79-94. https://doi.org/10.1177/0887302X09332513

Kish-Gephart, J.J., Harrison, D.A. \& Trevino, L.K., 2010, 'Bad apples, bad cases, and bad barrels: Meta-analytic evidence about sources of unethical decisions at work', Journal of Applied Psychology 95, 1-31. https://doi.org/10.1037/a0017103

Krishnaveni, R. \& Deepa, D., 2013, 'Controlling common method variance while measuring the impact of emotional intelligence on well-being', Vikalpa 38(1), 41-48. https://doi.org/10.1177/0256090920130104

Liao, C., Lin, H.N. \& Liu, Y.P., 2010, 'Predicting the use of pirated software: A contingency model integrating perceived risk with the theory of planned behaviour', Journal of Business Ethics 92(2), 237-252. https://doi.org/10.1007/s10551-009-0081-5

Londono, J.C., Davies, K. \& Elms, J., 2017, 'Extending the theory of planned behaviour to examine the role of anticipated negative emotions on channel intention: The case of embarrassing product', Journal of Retailing and Consumer Services 36, 8-20. https://doi.org/10.1016/j.jretconser.2016.12.002

Malhotra, K.N., 2010, Marketing research: An applied orientation, 6th edn., Pearson Education International, Upper Saddle River, NJ.

McQuitty, S. \& Wolf, M., 2013, 'Structural equation modeling: A practical introduction', Journal of African Business 14(1), 58-69. https://doi.org/10.1080/15228916.2013. 765325

Meissner, R., 2010, 'The trade counterfeit goods: What is it, why is it a problem and what is its impact on Africa?', Polity Organisation, viewed 23 April 2019, from https://www.polity.org.za/article/the-trade-in-counterfeit-goods-what-is-it-whyhttps://wwW.polity.org.za/article/the-trade-in-counterfeit-goods-what-is-it-whyis-it-a-problem-and-what-is-its-impact-on-africa-2010-08-04/searchString:The+tr
ade+counterfeit+goods+What+is+it+why+is+it+a+problem+and+what+is+its+imp ade+counterfeit
act+on+Africa.

Meraviglia, L., 2018, 'Technology and counterfeiting in the fashion industry: Friends or foes', Business Horizons 18, 1-9.

Montandon, A., 2015, 'Retail in South Africa: Profile and future prospects', in T., Foscht, D., Morschett, T. Rudolph, P. Schnedlitz, H. Schramm-Klein \& B. Swoboda (eds.) European Research, vol. 27, pp. 125-152, Springler, Fachmedien, Wiesbaden. European Research, vol. 27, pp. 125-152, Spi
https://doi.org/10.1007/978-3-658-07038-0_5

News24, 2011, 'Counterfeit industry grows, tops R360 bn', News24, viewed 05 May 2019, from http://www.news24.com/SouthAfrica/Politics/Counterfeit-industrygrows-tops-R360bn-20111003.

Ohtomo, S. \& Ohnuma, S., 2014, 'Psychological interventional approach for reduce resource consumption: Reducing plastic bag usage at supermarkets', Resources, Conservation and Recycling 84, 57-65. https://doi.org/10.1016/j.resconrec. 2013.12.014

Organisation for Economic Cooperation and Development (OECD), 2009, Magnitude of counterfeiting and piracy of tangible products: An update, Organisation for Economic Cooperation and Development, viewed 03 April 2019, from www.oecd. org/sti/ind/44088872pdf.

Pallant, J., 2011, SPSS survival manual: A step by step guide to data analysis using SPSS, 5th edn., McGraw-Hill Education, Berkshire.

Papaoikonomou, E., Ryan, G. \& Valverde, M., 2011, 'Mapping ethical consumer behaviour: Integrating the empirical research and identifying future directions', Ethics and Behaviour 21(3), 197-221. https://doi.org/10.1080/10508422.2011.570165

Penz, E. \& Stottinger, B., 2005, 'Original brands and counterfeit brands - Do they have anything in common?', Journal of Consumer Behaviour 7(2), 146-163. https://doi. org $/ 10.1002 / c b .243$

Perumal, S. \& Sapihan, A.R., 2017, 'Analysing purchasing intention of counterfeit sportswear products Klang Valley, Malaysia', IOSR Journal of Business and Management 19(1), 77-81. https://doi.org/10.9790/487X-1901047781

Phau, I. \& Teah, M., 2009, 'Devil wears Prada: A study of antecedents and outcomes of attitudes and outcomes of attitudes towards counterfeits of luxury brands', Journal of Consumer Marketing 26(1), 15-27. https://doi.org/10.1108/ 07363760910927019

Phillips, T., 2007, Knockoff: The deadly trade in counterfeit: The true story of the world's fastest growing crime wave, Kogan Page, London.
Poddar, A., Foreman, J., Banerjee, S. \& Ellen, P.S., 2012, 'Exploring the Robin Hood effect: Moral profiteering motives for purchasing counterfeit products', Journal of
Business Research 65, 1500-1506. https://doi.org/10.1016/j.jbusres.2011.10.017

Podsakoff, P.M., MacKenzie, S.B., Lee, J.Y. \& Podsakoff, P.M., 2003, 'Common method biases in behavioural research: A critical review of literature and recommended remedies', Journal of Applied Psychology 88(7), 879. https://doi.org/10.1037/00219010.88.5.879

Sahni, A., 1994, 'Incorporating perceptions of financial control in purchase prediction: An empirical examination of the theory of planned behaviour', Advances in Consumer Research 2, 1442-1448.

Sarkis, A.M., 2017, 'A comparative study of theoretical behaviour change models predicting empirical evidence for residential energy conservation behaviours' Journal of Cleaner Production 141, 526-537. https://doi.org/10.1016/j. jclepro.2016.09.067

Schiffman, L.G., Kanuk, L.L. \& Wisenblit, J., 2010, Consumer behaviour, 10th edn., Pearson Education, Upper Saddle River, NJ.

Shunmugam, N., 2015, 'Consumer intentions of purchasing authentic luxury brands versus counterfeits in South Africa', Dissertation, Masters in Business Administration, Gordan Institute of Business, University of Pretoria, Pretoria.

Sondhi, N., 2017, 'Scale development and validation for assessing attitude towards counterfeit luxury', Procedia Computer Science 122, 206-213. https://doi. org/10.1016/j.procs.2017.11.362

Sopha, B.M., 2013, 'Sustainable paper consumption: Exploring behavioural factors', Social Sciences 2, 270-283. https://doi.org/10.3390/socsci2040270

South African Revenue Service (SARS), 2018, Drugs valued over $R 30$ million bust at OR Tambo this week, viewed 20 February 2019, from https://www.sars.gov.za/ Media/MediaReleases/Pages/13-April-2018---Drugs-valued-at-over-R30-millionbust-at-OR-Tambo-this-week.aspx.

Swami, V., Chamorro-Premuzic, T. \& Furnham, A., 2009, 'Faking it: Personality and individual difference predictors of willingness to buy counterfeit good', The Journal of Socio-Economics 38, 820-825. https://doi.org/10.1016/j.socec 2009.03.014

Tabachnick, B.G. \& Fidell, L.S., 2007, Using multivariate statistics, 5th edn., Pearson Education, Boston, MA

Tang, F., Tian, V.I. \& Zaichkowsky, J., 2014, 'Understanding counterfeit consumption', Asia Pacific Journal of Marketing and Logistics 26(1), 4-20. https://doi. org/10.1108/APJML-11-2012-0121

Thaichon, P. \& Quach, S., 2016, 'Dark motives counterfeit purchase framework: Internal and external motives behind counterfeit purchase via digital platforms', Journal of Retailing \& Consumer Services 33, 82-91. https://doi.org/10.1016/j. Journal of Retailing \&
jretconser.2016.08.003

Ting, M., Goh, Y. \& Isa, S.M., 2016, 'Determining consumer purchase intentions towards counterfeit goods in Malaysia', Asia Pacific Management Review 21, 219-230. https://doi.org/10.1016/j.apmrv.2016.07.003

Transcrime, 2010, Anti-brand counterfeiting in the EU: Report on international and national existing standards, Joint Research Centre on Transnational Crime, Milan.

Triandis, H.C., 1977, Interpersonal behaviour, Brooks, Monterey, CA.

Umar, B., 2015, 'Fight against counterfeit sports products grows as business booms', The Street, viewed 23 August 2019, from https://www.thestreet.com/video/fightagainst-counterfeit-sports-products-grows-as-business-booms-13046696.

Wang, Y. \& Song, Y., 2013, 'Counterfeiting: Friend or foe of luxury brands? An examination of Chinese consumers' attitudes toward counterfeit luxury brands', Journal of Global Marketing 26, 173-187. https://doi.org/10.1080/08911762.201 3.804618

Wee, C., Tan, S.-J. \& Choek, K.-H., 1995, 'Non-price determinants of intentions to purchase counterfeit goods', International Marketing Review 12, 19-47. https:// doi.org/10.1108/02651339510102949

Wilcox, K., Kim, H.M. \& Sen, S., 2009, 'Why do consumers buy counterfeit luxury brands?', Journal of Marketing Research 46(2), 247-259. https://doi.org/10.1509/ jmkr.46.2.247

Xi, E.A.C. \& Cheng, K.T.G., 2017, 'The determinants of purchase intention on counterfeit sportswear', Journal of Applied Structural Equation Modeling 1(1), 13-26.

Yeow, P., Dean, A. \& Tucker, D., 2014, 'Bags for life: The embedding of ethical consumerism', Journal of Business Ethics 125, 87-99. https://doi.org/10.1007/ s10551-013-1900-2

Zikmund, G.W. \& Babin, J.B., 2010, Essentials of marketing research, 4th edn., South-Western Cengage Learning, Mason, IA. 